\title{
THE ATTITUDE OF THE COURTS TOWARDS INDUSTRIAL PROBLEMS
}

\author{
By George Gorham Groat, \\ Ohio Wesleyan University, Delaware, Ohio.
}

Modern industry with its rapidly changing conditions has placed a heavy burden of responsibility upon our courts. Difficulties of adjustment unknown until recently have given rise to strife involving individual rights and social welfare. These contests have been taken to court. There the old-established principles constitute the standards. But these are not applicable to new conditions. Thus the courts face the necessity of trying to perform new tasks with old tools. Upon their ability to adjust themselves to the new requirements depends the peaceful solution of some of our most perplexing industrial problems. The responsibility is two-fold: first, that of passing on legislation that departs from former standards, and second, that of adjusting individual rights under conditions where collective activity prevails.

With the importance that is attached to precedent, it is unfortunate that so many cases have been decided in the past in a manner contrary to the public welfare. This thwarting of the public interest has generally resulted from a purpose to protect private interests and especially private property. Many of these cases are so widely known and the results so far beyond dispute that brief mention of them will suffice.

Although the Massachusetts court decided in favor of a law restricting the hours of labor for women as long ago as 1876, the court in Illinois, in 1895, refused to allow such a law to stand. It was an infringement upon the private right of citizens to contract for the length of day. The appeal of a case from the Oregon court to the federal supreme court and the elaborate opinion upholding the public necessity of such legislation has finally saved the situation. A new standard for such legislation has been established. The crux of interest was reached when the Illinois court, facing the material and the weight of authority of the nation's highest tribunal, finally reversed its own decision. The influence of the supreme court of the 
United States has been potent in several states since, and uniformly the principle is sustained. It should, however, be noted that in New York a decision still stands which holds invalid a law prohibiting women from working in certain industries during night hours. This legislation the New York court regards as an infringement upon the individual rights of some of its citizens.

The effort to restrict the hours of labor in underground mines affords another instance of failure to appreciate the importance of public welfare above private interest. In Colorado an eight-hour law was passed applicable to mines and smelters. The supreme court of the state held the law unconstitutional. This opinion, both in point of conclusion reached and of reasoning, is one of the most unsatisfactory and unconvincing that any of our courts has handed down. There appears to have been more behind it than simple legal considerations, if the following statements may be taken with authority. Writing in the Century Law Journal (vol. 62, p. 379 note), A. A. Bruce asserts that the case of In re Morgan "is so evidently the result of pique and injured dignity, arising out of the fact that the legislature disregarded the suggestions made by the court in the prior case of In re house bill, 21 Colo. 29, that it is worthy of but little consideration." Judge Lindsey, in Everybody's Magazine (Vol. 22, p. 242 note), says that "Even the laboring men, during these troubles, recognized that Judge Campbell's decisions were those of an honest prejudice due to his training and his temperament." This opinion was held by the Colorado court in spite of the fact that the same principle had been sustained by the supreme court of Utah, had been appealed to the federal court and there supported. This victory for the Utah measure did not assist in securing support for the Colorado law.

While the United States supreme court has these two decisions to its credit, there is another side to the account. One case is that of the New York bakeshop law. One of the provisions of this law was the limitation of the hours of labor for those working in bakery and confectionery establishments. The highest court of the state on appeal sustained the law. The supreme court of the United States held it unconstitutional. In this unusually interesting case twentytwo judges were on the benches of the several courts. Of these, twelve in all voted in favor of the law. In the highest state court it was sustained by a majority of one, and in the federal court it was overthrown by the same narrow majority. Five opinions were written 
by the New York judges and three in the federal court. Much of the argument that led to the annulling of the law is of the extreme conservative type. In some parts the opinions even border upon an attempt at the facetious, as where Judge Bartlett writes that the claims of danger to health in this industry "will surprise the bakers and good housewives of this state;" and further that the risks to health shown in the evidence are "not to be confounded with the avocation of the family baker, engaged in the necessary and highly appreciated labor of producing bread, pies, cakes and other commodities more calculated to cause dyspepsia in the consumer than consumption in the manufacturer." This opinion is to be classed as one of the most reactionary. The results were disastrous to a much-needed reform. The findings of a commission, the legislation based on those findings, and the views of the majority of the state's highest court all were set aside as unreasonable. The measure interfered with private rights. If the results are to be secured now it must be through the insistance of the bakers with prospects for a strike and much industrial loss. A further influence of this decision manifested itself as late as 1910 when the supreme court of Missouri on the authority of this opinion invalidated a law of that state, one of the provisions of which restricted bakers to a six-day week.

Even the briefest reference to this class of cases should not omit the widely known New York tenement house case. It has been the bulwark of protection of private property rights against public interests and in the view of most eminent authority it is directly responsible for the existence of tenement house problems, slums and sweatshops in all of our large cities. The opinion, it will be remembered, denied the constitutionality of a law prohibiting the manufacture of cigars in tenement houses. The basis of the opinion was the freedom of the property owner to the income from his tenement houses and the freedom of the occupant to engage in his own home in any occupation that pleased him. That is to say, the law was a violation of personal liberty and private property when conditions as understood by the court did not warrant it. In this opinion the justices strayed so far from the reality of the present-day tenement life as to refer to the situation created by the law as one that was intended to improve the health or the morals of the cigar-maker "by forcing him from his home and its hallowed surroundings and beneficent influences to ply his trade elsewhere." 
Space will not allow even brief reference to the experience of many of the states with social legislation. The socially necessary measures have often been subjects for legislation which courts have many times been called upon to test in the light of constitutionality. In some instances the laws have been upheld while in others they are annulled. The grounds on which the decisions are based are quite uniformly the unwarranted interference with property rights, individual rights and rights of contract. Industrial peace depends so directly upon the enactment of such laws that until courts come to view them as in accord with social necessity, and therefore not contrary to the requirements of the constitution, there must remain elements of discord.

Turning from this field of legislation it is necessary to consider the attitude of the courts when the activities of labor organizations are involved. Here there is also confusion. The difficult problem is in adjusting individual rights established in a day when industrial relations were simple to rights of groups in collective activity with industrial relations highly complex. The difficulties and the disagreements may well be illustrated by reference to strikes and boycotts. Slowly the right to strike freed itself from the charge of conspiracy and came to be generally recognized by the courts. But what are the limitations upon this right? The courts are not in agreement in their answer. Two views obtain and they are irreconcilable. One may be distinguished as the Massachusetts view and the other as the New York view. The former has been adopted in the majority of decisions. In the opinion of the Massachusetts court, as summed up by Judge Loring, "the legality of a strike depends . . . upon the purpose for which the employees strike." In support of this view, and in further definition of it, the same court has more recently said that "whether the purpose for which a strike is instituted is or is not a legal justification for it is a question of law to be decided by the court. . . . The strikers must in good faith strike for a purpose which the court decides to be a legal justification for such interference. . . . A strike is not a strike for a legal purpose because the strikers struck in good faith for a purpose which they thought was a sufficient justification for a strike." The court nowhere defines the legal purpose in such a way that unions may be guided by the definition. Each instance must come as a separate case to be decided on its merits. 
Compared with this view, that of the New York court seems extreme. As formulated by Chief Justice Parker it held in the most unqualified way that laborers may strike for any reason that seems to them sufficient. These reasons they need not even state. If they do choose to express them "their right to stop work is not cut off because the reason seems inadequate or selfish to the employer or to organized society." Here is a situation that contributes to industrial restlessness, and evidently must continue to do so as long as a strike that is legal in one state would not be so regarded by the court of another commonwealth.

Though boycotts are so generally connected with strikes the courts treat them on quite different principles. The motive is generally held as material, and as it is to harm the business of another in order to force a concession on the part of its owner, that motive is easily understood to be unlawful. As to the present legal status of boycotts there can be no doubt. In some states they have been the subject of statutory enactment. Courts have decided very positively against them. The United States supreme court has held that they are not only in violation of freedom of interstate commerce but are violative of common law rights of property. "There is no doubt," it declares, "that at common law every person has individually, and the public also has collectively, a right to require that the course of trade should be kept free from unreasonable obstructions." In the Bucks Stove and Range boycott case this same court refers to printed statements such as "unfair" and "we don't patronize" as "verbal acts" expressive of "force not inhering in the words themselves, and therefore exceeding any possible right of speech which a single individual might have." In spite of these expressions, other opinions indicate that a distinction is beginning to appear. While the development is much tardier than in the case of strikes, there is a positive note indicating that the boycott is not to be uniformly condemned. If practiced within limits it is allowed in some jurisdictions. Even the principle accepted by the federal court is not followed by some state courts. The line of reasoning in these latter cases is too long to trace here. Four opinions may be introduced as evidence, however: Payne v. Western Atlantic Railroad Co. (Tennessee, 49 Am. Rep. 666); Marx \& Haas Jeans Clothing Co. v. Watson (Missouri, 67 S. W. 391); Lindsay \& Co. v. Montana F. of L. (Montana, 96 Pac. 127); Parkinson Co. v. Building Trades Council (California, 
98 Pac. 1027). In a still later case, Pierce $v$. Stablemen's Union, the California court goes even further in refusing to declare a boycott per se illegal. It argues that one may bestow or withhold his patronage as it may please him, thus placing the boycott on the same broad principle as the strike. With the primary goes the secondary boycott, in the opinion of this court. Going further, perhaps, than any other opinion, it is held that strikers may engage in a boycott; meaning that they may withdraw social and business intercourse by all legitimate means, and by "fair publication and fair oral or written persuasion" may induce others to do the same. They may go further and use "moral intimidation and coercion" to "threaten" a like boycott, thus bringing in third persons, a secondary boycott. Here the court takes what it characterizes as "advance ground" and "recognizes no substantial distinction between the so-called primary and secondary boycott." Each of these forms rests upon the right of the union to control its own patronage and to induce by fair means others to do the same. As the unions would have the "unquestioned right to withhold their patronage from a third person who continued to deal with their employer," they must have the right to notify them of their intended action.

Such are some of the differences that have developed in the effort to formulate out of the old material principles that will be adaptable to the conditions of industry that prevail to-day. As with social legislation so in these instances evidence is not wanting that courts are making a distinct contribution to the interests of industrial peace, though disturbing elements are still present.

It is evident that before our courts can make themselves of the highest usefulness in solving the perplexing problems of the present and in establishing more firmly peaceful relations in industry, some very important changes must be made in their attitude. In a more elaborate study the writer has endeavored to show more in detail the important elements of this situation. In "The Attitude of American Courts in Labor Cases," extracts from a large number of opinions are brought together from which conclusions are drawn. Stated briefly because of the limitations of space these necessary changes must include the following.

The sacredness of precedent, an exaggerated form of respect for former opinions and an overdone desire to preserve continuity in legal decisions, undoubtedly result in checking healthful lines of 
progress and estopping some highly beneficial legislation. The courts exhibit at times an almost blind devotion to this principle, and so long as they continue in this extreme the cause of industrial peace must suffer. Adherence to precedent must be less rigid. If conditions have so changed as to alter the applicability of a legal principle, the knowledge of such conditions must be as clear and keen in the minds of the court as that of the principle This will bring greater freedom from the binding force of precedent and a correspondingly wider margin for variation to suit new conditions. There can be no doubt that blindness to conditions has led courts in the past into serious error, as they have insisted on enforcing a principle where conditions were no longer suitable for such a course.

Legal training, accountable for much that is reactionary, must be changed. Severe comment on the content of text-books, on the law's backward look and on the stereotyped phrase is already beginning to appear. The pages of law magazines are speaking in open criticism of the past and expressing clearly formed demands for the future to the end that courses of law be modernized and socialized. The relation between sociology and jurisprudence is a topic both timely and profitable. Some of our leading jurists have already indicated a sense of responsibility to the present as well as the past. The number is increasing. The sentiment that indicates hope for the future has been well expressed by Mr. Justice Holmes: "In my opinion economists and sociologists are the people to whom we ought to turn more than we do for instruction in the grounds and foundations of all rational decisions." Speaking again, this distinguished jurist declares that "the true grounds of decision are considerations of policy and of social advantage, and it is vain to suppose that solutions can be attained merely by logic and general propositions of law which nobody disputes." That an increasing number of judges appear to be adopting the principles thus expressed, though in our haste the increase may seem exasperatingly slow, is an element that greatly brightens the outlook. Yet changes in this direction must come at a greater pace, as at best they can manifest their results but slowly.

The former views of individual rights must be decidedly modified. They must be given a social content. The possibility of individual rights remaining unmodified amid rapidly changing conditions of society is very remote indeed. While the declarations of rights in our constitutions have uniformly declared in general terms for 
equality of personal rights, such rights have never been uniform in fact. Applicable at first to civil conditions they are now being carried over into the industrial field. Here the equality has been less evident. Yet our courts have not fully realized this and have continued to use expressions once full of meaning in real life but now quite empty. Judges, as well as others, must apply what is really a very commonplace fact, that where there is a practically unequal distribution of rights, and an effort is made to equalize it, rights and privileges can be enlarged on one side only by curtailing those on the other. To continue to insist on the inalienable right of one in face of an expanding right of another is highly impractical. The slave had nothing to say concerning his condition. The owner had unrestrained freedom. It was impossible to free the slave without a corresponding limitation of the rights of the former master. Under conditions of individual wage contract it may fairly be assumed that in an earlier generation the rights to contract were about equal. More and more it is now true that men are employed by proxy and are hired in gangs. Conditions of labor are fixed by the employer and the laborer may accept them or let the work alone. Collective bargaining is one means of equalizing the situation. Yet when this method becomes so effective as to turn the tables against the employer and leave him a similar alternative, courts see differently. The federal supreme court in the Bucks Stove and Range boycott case discovers the inequality when it says, "But the very fact that it is lawful to form these bodies [labor unions], with multitudes of members, means that they have thereby acquired a vast power, in the presence of which the individual may be helpless." When collective bargaining has not accomplished a needed result, legislatures have sought to equalize the conditions by statute. Some courts accept such measures as of practical necessity. Others reject them. The course of procedure in cases where these laws are overthrown is quite uniform. The argument presented is that the law is an infringement upon rights of contract. The employee is not at liberty to contract for long hours, irregular pay or some other conditions unfavorable to him. The employer thus takes up the fight in behalf of his employee whom the legislature is seeking to deprive of his constitutional rights. Hearing these rights expressed in the conventional form of individual relations, the courts lose sight of the conditions that really determine the situation and the decision is handed down in favor of 
the employer's contention. Be it said that at least twice the court has seen the real situation in the case. Once the Washington court points out that the law is contested only by contractors who would reap benefits by the law's repeal. Again, the federal supreme court shows that the employer virtually claims that the act "works a peculiar hardship to his employees whose right to labor as long as they please is alleged to be thereby violated." The opinion adds significantly, "the argument would certainly come with better grace and greater cogency from the latter class." Such interpretation of individual rights in modern industry as have been made in many of these cases cannot contribute much hopefulness for continued industrial peace. It is one of the lines in which most serious consequences follow. Constitutions are made instruments for depriving of their rights the very ones whom they are intended to protect and who stand most in need of their protection. A restatement of constitutional rights in terms social rather than individual is a change that is imperative.

Finally, a matter of prime importance in the interests of industrial peace is the attitude that courts take toward the common law. Common law is essentially changing in its nature. To contend that it has the permanency of the constitution seems wholly untenable. Yet such appears to be the view of some courts. The opinions in the recent cases of workmen's compensation may be taken in evidence, as they clearly show a difference of view and a tendency to confuse the common law with the principles of the constitution. In all of these cases it is freely admitted that the legislation is "economically, sociologically and morally sound." To speak of the common law as adequate to the problem, declares the Wisconsin court, "is to jest with serious subjects, to give a stone to one who asks for bread." Speaking more directly in relation to the common law the Massachusetts court is of the opinion that "the rules of law relating to contributory negligence and assumption of the risk and the effect of negligence by a fellow servant were established by the courts, not by the constitution, and the legislature may change them, or do away with them altogether as defenses." Compared with these views the New York court manifests a different attitude toward this subject. The confusion appears most plainly when the opinion states that "The statute, judged by our common law standards, is plainly revolutionary. . . The radical character of this legislation 
is at once revealed by contrasting it with the rule of the common law. . . Under our form of government, however, courts must regard all economic, philosophical and moral theories, attractive and desirable though they may be, as subordinate to the primary question whether they can be molded into statutes without infringing upon the letter or spirit of our written constitutions. . . .

When our constitutions were adopted it was the law of the land that no man who was without fault or negligence could be held liable in damages for injuries sustained by another. . . . It is conceded that [the liability in the new law] is a liability unknown to the common law and we think it plainly constitutes a deprivation of liberty and property under the federal and state constitutions."

In discussing thus the work of the courts it must not be inferred that they do not serve a useful purpose. Conservative forces society must have or there would be no continuity. Courts conserve our former experiences and enable us to profit by them. So long as changes come slowly there is time for a readjustment with less friction. But in our day changes come with unparalleled rapidity. Friction must be present because of the very nature of the work that our courts have to do. It may be greatly lessened, however, if judges will realize the facts and endeavor to be governed by them. A greater degree of socialization must come. At present it is coming without much assistance from the courts. It need not be so. With such changes accomplished as have been indicated the progress toward the socialization of industries will be rapid. The situation cannot be summed up in brief better than in the words of the opinion from the Wisconsin court: "When an eighteenth century constitution forms the charter of liberty of a twentieth century government, must its general provisions be construed and interpreted by an eighteenth century mind surrounded by eighteenth century conditions and ideals? Clearly not. This were to command the race to halt in its progress, to stretch the state upon a veritable bed of Procrustes." 